\title{
TWORZENIE KOALICJI REGIONALNYCH A EWOLUCJA SYSTEMU WIELOPOZIOMOWEGO W OPINII MARSZAŁKÓW WOJEWÓDZTW OD I DO V KADENCJI*
}

\author{
FORMATION OF REGIONAL COALITIONS AND CREATION \\ OF A MULTI-LEVEL SYSTEM IN POLAND IN THE OPINIONS \\ OF VOIVODESHIP MARSHALS (HEADS OF REGIONAL \\ GOVERNMENT) IN OFFICE IN 1998-2014
}

Tatiana Majcherkiewicz**

\begin{abstract}
ABSTRAKT
Artykuł ten w oparciu o opinie marszałków województw rekonstruuje rolę aktorów regionalnych i centralnych przy podejmowaniu decyzji dotyczących tworzenia koalicji regionalnych w okresie od I do V kadencji. W warstwie teoretycznej analiza odwołuje się do perspektywy rządzenia wielopoziomowego, natomiast szczególnie istotna przy opisie wzorów tworzenia koalicji regionalnych od III do V kadencji jest koncepcja koalicji przystających (congruent coalitions). W związku $\mathrm{z}$ trwałością utrzymywania się $\mathrm{w}$ regionach koalicji PO-PSL zadane zostało pytanie o korzyści istnienia na tym poziomie podobnych koalicji jak w centrum. Dwie pierwsze kadencje znacząco odbiegały od trendów utrzymujących się od
\end{abstract}

The article reconstructs the influence of regional and national politicians in deciding on the formation of regional coalitions in the period 1998-2014 by referring to opinions presented on this issue by voivodeship marshals. The theoretical framework is a multi-level government perspective. Since the election of 2006, a particularly important concept in explanation of regional coalitions is that of congruent coalitions. Due to the durability of the Civic Platform/Polish Peasant Party coalition formula, regional politicians were asked about the advantage of forming congruent coalitions. The first and second terms of regional government (period 1999-2006) differ radically from the trend developed in the aftermath of

* Opracowanie to jest częścią projektu badawczego zatytułowanego: „Rekrutacja i skład społeczno-demograficzny regionalnych elit samorządowych w latach 1998-2014”. Badanie dofinansowane jest przez Narodowe Centrum Nauki (nr projektu: 2013/11/B/HS6/01196).

** Uniwersytet Pedagogiczny im. Komisji Edukacji Narodowej w Krakowie, Wydział Humanistyczny. 
chwili wyborów w 2006 r. W tym czasie politycy regionalni często podejmowali kluczowe decyzje i dopiero rozpoczynało się tworzenie systemu wielopoziomowego.

Słowa kluczowe: koalicje regionalne, rządzenie wielopoziomowe, koalicje przystające, partie polityczne, politycy centralni i politycy regionalni the 2006 election. At that time, the multi-level system was only beginning to develop, and it was regional politicians who were determining the formation of regional coalitions.

Keywords: regional coalitions, multi-level government, congruent coalitions, political parties, national and regional politicians

Artykuł ten jest przyczynkiem do studiów nad tworzeniem koalicji wojewódzkich $^{1}$ oraz kształtowaniem się wielopoziomowego systemu politycznego; rekonstrukcją opinii marszałków województw dotyczącą tych kwestii. Marszałkowie są aktorami regionalnymi, w wielu przypadkach uczestniczącymi w przetargach koalicyjnych, a niekiedy decydującymi o ich powstaniu. Odwołując się do perspektywy rządzenia wielopoziomowego (Multilevel Government, MLG), przyjmuje się, że wzoru tworzenia koalicji regionalnych nie można wyjaśnić jedynie na podstawie klasycznych teorii. Przyjmują one bowiem, że koalicje zawierane są wyłącznie w celu realizacji celów programowych lub traktują stanowiska jako łupy. Powstawanie koalicji wojewódzkich określone jest przez uwarunkowania regionalne; m.in. wyniki wyborów, ewolucję regionalnej sceny politycznej oraz zakres władzy samorządu regionalnego. Ważne jest również dostrzeżenie wpływu czynników związanych z polityką ogólnokrajową - poziomem centralnym² ${ }^{2}$ Wyniki międzynarodowych badań porównawczych (Back, Debus, Müller, Bäck, 2013) wskazują, jako że struktury subnarodowe partii

1 Szczegółowy opis składu politycznego koalicji wojewódzkich i wzorów ich tworzenia z odwołaniem do teorii klasycznych i perspektywy rządzenia wielopoziomowego przedstawiony jest [w:] Majcherkiewicz (2016).

2 W ramach badań MLG, koncentrujących się na koalicjach regionalnych, oddziaływanie innych szczebli ogranicza się głównie do poziomu centralnego, ale w innych analizach politologicznych w ramach szeroko rozumianej perspektywy rządzenia wielopoziomowego także oddziaływanie poziomu europejskiego jest często silniej wyeksponowane. Dla perspektywy MLG niezależnie od obszaru szczegółowych badań ważne są trzy główne założenia. Po pierwsze, polityki różnych poziomów wzajemnie na siebie oddziałują; w przypadku koalicji regionalnych duży wpływ na ich kształt polityczny ma polityka centralna, ale nie jest to relacja jednostronna, przykładowo koalicja innowacyjna PO-PSL, dobrze funkcjonująca w wielu regionach, odtworzona została na szczeblu centralnym w 2007 r. (porównaj: Downs, 1998). Po drugie, MLG bardzo silnie podkreśla wzrost znaczenia polityki regionalnej i przedefiniowanie relacji pomiędzy centrum i regionami, m.in. odrzuca się hierarchiczny, jednokierunkowy typ relacji. Po trzecie, perspektywa ta podkreśla, że wzrost roli regionów związany jest również z oddziaływaniem polityki europejskiej (Deschouwer, 2001). Szczegółowe omówienie 
podporządkowane są poziomowi ogólnokrajowemu, to regiony muszą częściej uwzględniać ograniczenia i uwarunkowania funkcjonowania w systemie wielopoziomowym; preferencje szczebla centralnego niż w drugą stronę (tego, że centrum uwzględnia uwarunkowania regionalne). Innymi słowy ograniczenia związane z funkcjonowaniem systemu wielopoziomowego stają się czynnikami ważniejszymi niż założenia sformułowane przez klasyczne teorie koalicji. Irina Ştefuriuc (2013) sformułowała cztery założenia, które muszą być uwzględniane przy analizie koalicji regionalnych.

1. Partie nie sa unitarnymi aktorami; $\mathrm{z}$ tego wynika, że aktorzy regionalni i centralni mogą realizować do pewnego stopnia inne polityki.

2. Partie nie dąż tylko do zrealizowania pojedynczego celu politycznego; przykładowo dla polityków regionalnych najważniejsze może być zdobycie stanowisk i będą zwolennikami zawarcia koalicji z partią X., natomiast politycy centralni mogą być temu przeciwni, ze względu na fakt, iż jest to partia opozycyjna na poziomie ogólnokrajowym.

3. Wielowymiarowość celów programowych - aktorzy centralni i regionalni mogą się też różnić celami programowymi.

4. Warunek ten wydaje się być najważniejszy; tworzenie koalicji w systemie wieloszczeblowym jest gra zagnieżdżoną. Odwołując się do teorii gier, przyjąć należy perspektywę postrzegania przetargów koalicyjnych jako gry, nieograniczającej się w swoim zakresie tylko do zawarcia koalicji w pojedynczym regionie (określa się ją jako pojedynczą rozgrywkę [sub-game]), ale w sposób całościowy jako gry złożonej, rozgrywającej się (zagnieżdżonej) w ramach systemu wielopoziomowego. Postrzeganie przetargów koalicyjnych jako gry zagnieżdżonej umożliwia wyjaśnianie takich rozstrzygnięć politycznych jak funkcjonowanie rządu mniejszościowego lub zaproszenie do koalicji dodatkowej partii. Zachowania takie trudno byłoby wyjaśnić jako racjonalne, analizując je tylko z perspektywy pojedynczej gry. Ştefuriuc (2013) podkreśla potrzebę prowadzenia przez partie polityczne skoordynowanej polityki wielopoziomowej, gdyż jej brak prowadzi do niespójności przekazu politycznego i może zrażać zarówno potencjalnych wyborców, jak i członków partii.

Jak podkreśla Ştefuriuc (2013), w przypadku systemu wielopoziomowego należy odejść od uproszczonej perspektywy, zakładającej, że regiony poddawane

założeń perspektywy rządzenia wielopoziomowego dotyczącej wzorów tworzenia koalicji regionalnych [w:] Majcherkiewicz (2017, w przygotowaniu do druku). 
są zewnętrznym interwencjom wyższego szczebla. W państwach, w których rozwinął się system wielopoziomowy, zachodzi wysoki poziom interakcji pomiędzy politykami różnych szczebli. Politycy regionalni i centralni mają też podobne poglądy, a skuteczne działanie partii wymaga skoordynowanej strategii.

W oparciu o literaturę przedmiotu $\mathrm{w}$ artykule postawione zostały trzy szczegółowe pytania badawcze. Oto dwa pierwsze: Jaka była rola ośrodka regionalnego; poczucie wpływu, autonomii w podejmowaniu decyzji lub przeciwnie - odczucie bycia podporządkowanym lub zdominowanym przez centrum? W jakim stopniu centrum konsultowało i/lub wpływało/wywierało nacisk (jego przejawy oraz ich pozytywna lub negatywna ocena)? Szczególnie ważne było zwrócenie uwagi na to, na jakim „szczeblu” zapadały decyzje oraz to, czy w przypadku, kiedy rozstrzygnięcia polityczne odzwierciedlały preferencje polityków regionalnych, to czy były one konsultowane/koordynowane w ramach polityki wielopoziomowej, czy były autonomiczne? Dodatkowo, czy zdarzały się wybory koalicji wojewódzkich sprzeczne z preferencjami polityków centralnych.

Trzecie pytanie badawcze odwołuje się do kwestii przystawalności koalicji. W ramach perspektywy MLG jednym z czynników mającym największy wpływ na tworzenie koalicji jest kwestia ich przystawalności (congruence; Ştefuriuc, 2013; Deschouwer, 2009). Wyodrębnić można trzy kategorie. Pierwszy typ to koalicja w petni przystająca, gdy te same partie rządzą na szczeblu centralnym i regionalnym. Druga kategoria to koalicja w pełni nieprzystająca (albo alternatywna), tworzona przez partie będące w opozycji na szczeblu krajowym. Podstawą jej wyróżnienia jest to, że nie przecina ona zasadniczej linii podziału w polityce ogólnokrajowej na rząd i opozycję. Trzeci rodzaj koalicji - częściowo przystajaca - to przykładowo dwie koalicje powstałe w 2014 r.: pierwsza w województwie opolskim - koalicja PO-PSL poszerzona o Mniejszość Niemiecką $(\mathrm{MN})$, natomiast w województwie śląskim trzecim partnerem koalicyjnym zostało SLD. W przypadku tej ostatniej koalicji była ona nie tylko koalicja częściowo przystająca, ale także koalicją określoną jako koalicja krzyżująca (cross-cutting; Pappi, Becker, Herzog, 2005 [za:] Ştefuriuc, 2013 oraz [za:] Bäck i in., 2013), gdyż przecinała główną linię podziału w polityce ogólnokrajowej - na rząd i opozycję̧ .

3 Jednak Ştefuriuc (2013) zwraca uwagę na tendencję do zmiany koalicji regionalnych po wyborach parlamentarnych i powstaniu nowego rządu centralnego. Dla rządu regionalnego często ważne i korzystne jest nawiązanie współpracy z partią rządową, nawet jeżeli dzieli je duży dystans ideologiczny. 
Linhart (2016), odwołując się do najnowszych trendów dotyczących tworzenia koalicji w krajach związkowych w Niemczech, kiedy to tworzenie koalicji w pełni przystających staje się coraz rzadsze, proponuje poszerzenie stosowania terminu congruence. Autor ten argumentuje, że zasadnicze założenie dotyczące przystawalności można dostosować do opisu aktualnie istniejących koalicji, jeżeli przyjmie się bardziej elastyczne jego rozumienie. Proponuje cztery sposoby rozumienia terminu koalicja przystająca. Pierwsze, to tradycyjne rozumienie - pokrywa się z dotychczasową koncepcją koalicji w pełni przystającej. Druga, szersza definicja: jako koalicje przystające uznaje także koalicje w pełni nieprzystające lub częściowo nieprzystające, czyli wszystkie warianty koalicji tworzonych przez partie opozycyjne, jak długo nie przecinają one podziału centralnego na rząd i opozycję. Według trzeciego sposobu rozumienia terminu koalicja przystająca występuje wtedy, gdy rząd regionalny tworzony jest przez co najmniej jedną partię rządową ze „szczebla” centralnego i równocześnie z uczestnictwa w niej wykluczone są ogólnokrajowe partie opozycyjne. Ostatni, najszerszy sposób rozumienia tego terminu występuje, gdy w rządzie regionalnym jest co najmniej jedna partia opozycyjna na „szczeblu” centralnym, ale nie ma partii rządowej, co powoduje utrzymanie ogólnokrajowego podziału na rząd i opozycję. Innymi słowy koalicje od 2 do 4 sposobu rozumienia tego terminu można też określić jako koalicje przystające w szerokim rozumieniu tego pojęcia, gdyż nie są koalicjami krzyżującymi. W artykule tym termin przystawalność będzie odwoływał się do szerokiego sposobu jego rozumienia.

Podstawą analizy przedstawionej w tym artykule stały się wywiady swobodne przeprowadzone z marszałkami województw od I do V kadencji (wybranych na ten urząd do końca 2014 r. - załącznik 1). Dodatkowo korzystano z dokumentów urzędowych (głównie uchwały sejmików). Dodatkowym źródłem informacji była prasa lokalna: relacje z obrad sejmików i wypowiedzi głównych aktorów regionalnych w nich uczestniczących.

Odwołanie się do metody wywiadów swobodnych było źródłem cennych danych, ale też wpłynęło na strukturę artykułu. Podążając za głosem rozmówców, dwa pierwsze pytania badawcze okazały się adekwatne do opisu zawierania koalicji tylko do 2006 r., natomiast od III kadencji omawiany jest jedynie stosunek do kwestii przystawalności koalicji. 


\section{KADENCJA}

Marszałkowie wybrani po wyborach samorządowych w 1998 r. uważali, że główne decyzje dotyczące kształtu politycznego koalicji zapadały w województwach i podejmowali je aktorzy i instytucje regionalne. Znaczący był wpływ radnych sejmików i szefów regionalnych struktur partii (a w przypadku prawicy także liderów regionalnych struktur związkowych).

Zarazem w przypadku tej kadencji poważny problem interpretacyjny wynika z faktu, że do 2001 r. można było łączyć m.in. funkcję posła i radnego sejmiku. Aby bardziej przybliżyć tę sytuację, przywołajmy przykład ukazujących rzeczywiste problemy klasyfikacji tych „wielopoziomowych” polityków - Henryk Długosz; przewodniczący sejmiku (do 2001 r.), poseł i szef SLD w województwie świętokrzyskim.

Ze względu na silne umocowanie tych liderów w strukturach regionalnych, w tym także w sejmikach, co umożliwiało im bezpośrednio oddziaływanie na politykę regionalną (w tym także na kształt koalicji), zdecydowano się ich zaklasyfikować jako przede wszystkim polityków regionalnych. Również marszałkowie tej kadencji postrzegali ich jako polityków regionalnych, zaangażowanych w sprawy województwa (przeprowadzone wywiady ukazują także bardzo ograniczony wpływ centrum w tej kadencji): „Po prostu radni sejmiku, ponieważ tam mogli być i posłowie i senatorowie; był poseł A, senator B, ale było też dwóch posłów z PSL-u. To były osoby, które w swoich partiach miały na tyle silną pozycję, że oni jako radni tego sejmiku... Kluby w sejmiku, nie pytały swojej partii na poziomie wojewódzkim, nie pytały, co my mamy robić. Oni byli osobowościami..." (respondent 1$)^{4}$.

Nawet w przypadku PSL i SLD - ugrupowań o skrystalizowanych strukturach centralnych, poważnym wyzwaniem było stworzenie nowych struktur regionalnych partii (opartych o nową siatkę województw). Zasadnicze decyzje podejmowali szefowie regionalnych struktur partii (dominowały osoby z województwa,

4 Zgodnie ze standardami w tego typu badaniach respondenci poinformowani zostali, że zachowana zostanie anonimowość ich wypowiedzi. W związku z tym, w niektórych cytatach, jeżeli było to konieczne, pomijane są szczegóły umożliwiające identyfikację rozmówcy. Zdecydowano się też nie podawać innych dodatkowych informacji dotyczących marszałka, np. nazwa województwa, partii politycznej, którą reprezentuje, lub kadencje, w których sprawuje urząd, gdyż w niektórych przypadkach umożliwiłoby to identyfikację rozmówcy. Przykładowo w województwie mazowieckim udział w badaniach wzięła tylko jedna osoba i można przypuszczać, że stosunkowo łatwo byłoby ustalić jej tożsamość. 
w którym usytuowana była nowa stolica) w konsultacji z marszałkami i radnymi. Choć w niektórych z tych regionów pozycja marszałka była słabsza, jednak nawet wówczas byli oni informowani o negocjacjach w trakcie spotkań liderów partyjnych z radnymi przyszłych klubów koalicyjnych ${ }^{5}$. To, że ośrodkiem decyzyjnym był sejmik, a nie struktury regionalne partii politycznych, wzmacniało odczucie sprawstwa i autonomii, jaką wyrażali marszałkowie tej kadencji: „Cały ciężar spadał w negocjacjach na prezesa zarządu wojewódzkiego PSL, w tamtym czasie był to Z. On prowadził rozmowy i z jedną i drugą stroną [z AWS i SLD - wtrącenie TM], jednak uznaliśmy, że na tamten czas to jednak koalicja z SLD będzie koalicją stabilną i taką koalicją, która da możliwość tworzenia dobrej instytucji samorządowej. Rozmowy prowadził prezes partii z jednej i z drugiej strony. Z naszej strony był to pan Z., z drugiej strony był B." (respondent 2).

Podobna wypowiedź marszałka z SLD, odwołująca się do wyboru kandydata na marszałka, wskazuje na decydujące znaczenie regionalnych polityków: „Tu bardziej decydowały te struktury wojewódzkie. Nie było takiego namaszczania, że władze krajowe musiały powiedzieć. (...) Na tamtym etapie bardziej pozycja danej osoby w województwie decydowała o tym, niż wskazanie centrali. Dzisiaj mam wrażenie jest trochę inaczej" (respondent 3).

Jeszcze silniejsza w negocjacjach była pozycja przyszłych marszałków z AWS, gdyż problemy zbudowania nowych struktur regionalnych były dla rozdrobnionej prawicy znacznie poważniejszym wzywaniem. Innymi słowy, to oni byli głównymi decydentami: „Również szefowie struktur partyjnych byli obecni. Oni jakby byli trochę w zapleczu, mieli ze sobą kontakty. Natomiast nie było tak, żeby oni decydowali o szczegółach. (...) Natomiast w naszym przypadku szefem partyjnym był... (...) struktury dopiero się montowały, bo one jakby były z X. [liczba byłych województw - TM] województw. (...) Dopiero się tworzyła cała struktura województwa N., tak że brali początkowo w tych rozmowach udział szefowie, ale potem już zostawiali mi wolną rękę co do rozmów" (respondent 4).

Podobny był opis powstania koalicji AWS-UW w innym województwie. Również tam aktorzy regionalni zadecydowali o kształcie koalicji regionalnej, choć w tym przypadku marszałek bardzo silnie akcentował rozdrobnienie prawicy i w związku z tą sytuacją to liderzy związkowi mieli największy wpływ.

5 Do pewnego stopnia relacje te różnią się od przedstawionych przez Nikolskiego (2011) strategii realizowanych przez partie uczestniczące w przetargach koalicyjnych. Analiza zarysowana przez Nikolskiego przedstawiona jest z poziomu ogólnokrajowego; celów i strategii partii. Inne usytuowanie instytucjonalne marszałków do pewnego stopnia zmodyfikowało ich ogląd sytuacji. 
Opisując I kadencję, działania zmierzające do tworzenia polityki koalicyjnej w ramach systemu wielopoziomowego i ogólnie kształtowanie się relacji pomiędzy poziomem centralnym a regionalnym, dostrzec trzeba wyjątkowość tego okresu. Argumentuje się że, działania polityczne zmierzające do budowania w pełni rozwiniętego systemu wielopoziomowego rozpoczynają się po I kadencji. Wyjątkowość tej kadencji w oparciu o wypowiedzi marszałków wynikała $\mathrm{z}$ dwóch podstawowych uwarunkowań. Po pierwsze ograniczony był zakres decentralizacji, w związku z tym niewielkie było znaczenie samorządu województw. Po drugie powodowało to z kolei małe zainteresowanie centrum polityką regionalną.

Marszałkowie województw I kadencji jednogłośnie podkreślali ograniczony zakres władzy samorządu województw, wynikający (co do przyczyny ich opinie były również jednogłośne) z dostępu tylko do bardzo ograniczonych środków finansowych. Poniżej jedna z takich wypowiedzi: „Nie było jeszcze wtedy tych pieniędzy, które pojawiły się później. Myśmy byli biedni jak mysz kościelna. Subwencje drogowe to był jedyny kawałek pieniędzy, z których coś można było zrobić. Administracja była zapuszczona. Trzeba było wyremontować, wyposażyć pomieszczenia, dokonać jakichś zmian i tak dalej. Tych środków nie było przesadnie dużo, grubo za mało na te cele, o które chodziło. Jeszcze nie było tego, co się pojawiło wraz z pieniędzmi unijnymi. Wtedy województwa stały się kawałkiem władzy realnej; temu mogę nasypać, a temu nie. Mogę być dobry tu, a tam nie; mogę spowodować, że będzie sukces tu, a tam spowodować - jakby to powiedzieć - porażkę" (respondent 5).

W związku z tym, często politycy ogólnokrajowi byli mało zainteresowani ich aktywnością, pozostawiając politykom regionalnym „wolną rękę w podejmowaniu decyzji”. Działania polityków centralnych ukierunkowane na tworzenie wielopoziomowej strategii koalicyjnej były bardzo ograniczone. Niedostrzeganie znaczenia samorządu województwa przez centrum ilustruje poniższy cytat (zdecydowano się umieścić go w tym miejscu, pomimo że pochodzi z II kadencji, równocześnie wskazuje on, że w przypadku niektórych partii prawicowych ten typ myślenia utrzymał się także po wejściu do Unii Europejskiej): „Wtedy nie było jeszcze takich dużych pieniędzy, w centrali, jeszcze nie rozumieli, jak to właściwie funkcjonuje. Pierwsze rozdanie unijne to raczej tutaj lokalnie wszystko było załatwiane. Zbyt wielu kontaktów z Warszawą nie było. Nie było nacisków. Natomiast ci nasi lokalni posłowie bardzo rozsądnie do tego podchodzili, normalnie rozmawialiśmy.(...) Tutaj naprawdę, jak myśmy przejęli władzę, to był naprawdę dobry okres, największe inwestycje ściągnęliśmy. Dziś wszyscy 
wspominają, że takiej współpracy jak wtedy nie było, bo się nigdy nie kłóciliśmy. Na kolegów z X. [nazwa partii - TM] też nikt nie wpływał, więc mieliśmy pełną swobodę działania" (respondent 6).

Pomimo opisanych trudności związanych $\mathrm{z}$ instytucjonalizacją samorządu województw i budowaniem struktur regionalnych partii, PSL już w I kadencji prowadziło politykę wielopoziomową. Dwóch z trzech marszałków tej kadencji z PSL-u, którzy uczestniczyli w badaniach, wspominało o uzgodnieniach i planach strategicznych formułowanych w centrum.

Jednak dostrzec trzeba jeszcze jeden wymiar oddziaływania „szczebla” centralnego. Choć politycy centralni raczej nie dostrzegali wagi samorządu regionalnego, to jednak $\mathrm{w}$ momencie powstawania koalicji regionalnych oddziaływał istniejący wówczas ogólnokrajowy podział polityczny - „podział postkomunistyczny" (Grabowska, 2004; Raciborski, 2006) i znajdował on swoje odzwierciedlenie na poziomie barier psychologicznych i w kontaktach osobistych. Czołowi politycy regionalni z SLD i PSL znali się od wielu lat, podobnie jak w innych regionach politycy prawicy: AWS i UW. Czasami nawet mówiono o przyjaźniach w ramach poszczególnych „obozów”: „Mam wrażenie, że to nie była decyzja jednoznaczna, w sensie decyzji politycznej, przedyskutowanej, umówionej gdzieś na poziomie centralnym, ona wynikała - moim zdaniem, z tamtych czasów. Według mnie wówczas, w 1998 r., nadal SLD oczywiście, ale PSL również, był traktowany jako element postkomuny".

"Jednak?"(T.M.).

„Moim zdaniem tak. Co prawda u nas w sejmiku AWS próbował czasami flirtować z PSL-em, dawał takie oznaki w wypowiedziach, w trakcie jakichś tam dyskusji na sesjach sejmiku, że PSL to jest taki, ..." (respondent 1).

„Czyli prawica go odrzucała...”(T.M.).

„Według mnie tak. Kiedy negocjowaliśmy z PSL-em, X. [szef PSL-u w regionie - TM] powiedział, że miał propozycję z AWS-u, żeby w ogóle spotkać się i rozmawiać. Nie to, że koalicja, ale w ogóle, żeby spotkać się i rozmawiać. Nie pamiętam tego, ale mam wrażenie, jakoś to w taki sposób prawie że wesoły, ośmieszający, powiedział, że: „Nie, będziemy z nimi gadać”. Także jakaś próba była, ale wyglądało, że ona była wręcz zlekceważona przez PSL (...). Myślę, że w województwie A. PSL dogadał się szybciej z SLD, mogło to wynikać też z tego, że P. dobrze znał G., i byli, że tak powiem, w dobrych, koleżeńskich stosunkach. To mogło mieć duże znaczenie, bo szef AWS-u, pan L. (...) w Sejmiku był dla nas wszystkich osobą obcą, osobą z drugiej dla nas części, i dla PSL-owców też. 
Osobą jednak z drugiej strony barykady. Proszę pamiętać, właśnie się skończyła kadencja sejmu, kadencja rządu, gdzie PSL z SLD przeciwko, nie AWS-owi, ale przeciwko ekipie, że tak powiem, solidarnościowej występował. Tu istniała również taka bariera, moim zdaniem, bardziej psychologiczna, że łatwiej było się dogadać nam: „Oto, zobaczcie, tam w Warszawie straciliśmy władzę”, znaczy: my - PSL i wy - SLD straciliście władzę. Stracimy władzę w urzędach wojewódzkich, bo naszych ludzi usuwają, w związku z tym weźmy razem sejmik. I nikt tak głośno tego nie powiedział. Myślę, że taki mechanizm mógł zadziałać, że w sumie dosyć łatwo doszło do zawarcia koalicji między SLD a PSL w tym pierwszym sejmiku" (respondent 1).

\section{KADENCJA}

Po wyborach w 2002 r. utrzymywał się duży wpływ ośrodka regionalnego, marszałkowie wskazywali, że to na tym poziomie zapadały wiążące decyzje. Oddziaływanie centrum pozostało nadal stosunkowo ograniczone. Znacząco osłabiało go rozdrobnienie polityczne, była to jedyna kadencja, w której nawet PSL deklarowało, że zrezygnowało z realizacji strategicznej, skoordynowanej polityki koalicyjnej i prowadziło oddzielne negocjacje koalicyjne w każdym z województw (taka taktyka umożliwiała mu jednak zawieranie koalicji zarówno z SLD, jak i prawicą). Zarazem kadencję tę odróżnia od wszystkich pozostałych to, że czasami - bardzo rzadko - niektóre z tych regionalnych wyborów politycznych były nie tylko niezależne, ale także sprzeczne z oczekiwaniami aktorów centralnych (sprzeczne były co najmniej 2 koalicje na 38).

Ponieważ w trakcie wywiadów swobodnych została zagwarantowana anonimowość rozmówcom, sprzeczności celów aktorów regionalnych i centralnych przedstawione zostały tylko wtedy, kiedy były one szeroko opisane w prasie lokalnej. Najwyraźniej konflikt dotyczący różnej wizji koalicji wojewódzkiej pomiędzy centrum a regionem zarysował się w województwie łódzkim w grudniu $2004 \mathrm{r}$. Struktury regionalne PSL były przeciwne dalszej współpracy z Samoobroną, uznając ją za destrukcyjnego partnera; m.in. wcześniej radni tej partii głosowali przeciwko budżetowi województwa, pomimo że ich partia pozostawała w koalicji (Łódź rozwodzi się z SLD, RMF FM). Zarząd wojewódzki PSL-u podjął uchwałę o koalicji z lewicą (SLD, Inicjatywa RP i Klub Aktywnych Radnych). Natomiast prezes PSL Wojciechowski - był zwolennikiem porozumienia z SPR: „Nadal nie 
rozumiem wyjścia Samoobrony z koalicji i niezłożenia dymisji z zajmowanych stanowisk w samorządzie. Muszę to wyjaśnić z Lepperem w cztery oczy" (Graja na dwa fronty, Gazeta Wyborcza, Łódź).

Rozdrobnienie polityczne sejmików spowodowało, że głównymi aktorami politycznymi w większości województw stali się marszałkowie, a nie szefowie struktur regionalnych partii, co odróżnia tę kadencję od poprzedniej. Najbardziej radykalny przykład dotyczy województwa dolnośląskiego. Radni należeli do ośmiu ugrupowań politycznych, a marszałkiem został Paweł Wróblewski, przedstawiciel partii, która po wyborach liczyła dwóch radnych (razem KW PO-PiS miał 6 radnych) i była piątą partią pod względem wielkości 6 . Po drugie, duży wpływ na kształt koalicji regionalnych mieli marszałkowie z lewicy. W województwach, gdzie SLD zachowała władzę, większość marszałków utrzymała swoje stanowiska, wzmacniało to ich pozycję przetargową i niektórzy z nich mieli rozstrzygający wpływ na wybór koalicjantów regionalnych.

Innymi słowy, tworzenie koalicji w przypadku dużego rozdrobnienia sejmików było trudne, często wymagało budowania nieformalnych sojuszy. Problemem wielu partii (prawicowych, a także SLD i Samoobronny, ale nie PSL) były też rozłamy wewnętrzne i przechodzenie radnych do innych klubów w sejmiku. W takich sytuacjach najskuteczniejsza była nie tylko decentralizacja decyzji, ale przekazanie ich marszałkom, gdyż rozstrzygająca była rola sejmików.

W przypadku niektórych regionów rządzonych przez lewicę, decydujący wpływ zachowali szefowie struktur regionalnych. Oddziaływanie centrum było opisywane jako ograniczone, nie do końca określone, co wydaje się wynikać z faktu, że marszałkowie nie uczestniczyli bezpośrednio w tych rozmowach. Odzwierciedla to poniższa opinia, która odwołuje się nie do znanych faktów, ale raczej do przypuszczeń: „Jeżeli chodzi o województwo, to na początku tak wiele na ten temat się nie mówiło, tego wpływu zewnętrznego. Teraz to już otwarcie, że na koalicję w województwach to się przekłada koalicja z góry. Jaka u góry, taka w województwach... (...) [Autor wypowiedzi odwołuje się do okresu, kiedy był marszałkiem - wtrącenie TM]. Ale władze polityczne, centralne - niewykluczone, że tutaj sugerowały dogadanie się..." (respondent 7).

Jednak na tym dominującym tle koalicji, które marszałkowie opisywali jako uzgadniane na poziomie regionalnym, wyróżnić można koalicję zawartą

6 O sprzeczności celów polityków centralnych i regionalnych świadczy także rezygnacja Wróblewskiego po trzech miesiącach od objęcia stanowiska marszałka $\mathrm{z}$ funkcji prezesa regionalnych struktur PiS (Kowalska, 2004). 
przez polityków centralnych: taką koalicją było czwórporozumienie kierujące województwem małopolskim (Kwaśniewski, 2002).

Analizując wpływ centrum, uznać można, że był on ograniczony; partie polityczne miały problemy w wypracowaniu całościowych, spójnych strategii. Trudności te wynikały także z rozdrobnienia politycznego, co jednak nie znaczy, że nie było innego rodzaju wpływu - były nim interwencje indywidualnych polityków ogólnokrajowych: „Kiepski był, szczerze mówiąc, tzn. u nas, jeśli chodzi o kolegów z A. [nazwa partii - TM], to ten jedyny polityczny w zasadzie element, o którym mówiłem; kiedy G. [nazwisko polityka centralnego - TM] potwierdził, że będzie robił na złość U. i L. [nazwiska polityków centralnych - TM] i wywala wszystkie nasze porozumienia. To był właściwie jedyny taki wpływ. Natomiast jeśli chodzi o kwestie merytoryczne, praktycznie nie było żadnych" (respondent 6).

Jednak przykładem najsilniejszego wpływu polityka indywidualnego (choć mającego pewne cechy strategii partyjnej ze względu na zajmowane przez niego stanowisko prezesa partii) uznać należy decyzję Andrzeja Leppera o zerwaniu koalicji regionalnych w kwietniu $2003 \mathrm{r}$.

\section{III, IV I V KADENCJA}

W III kadencji stabilizacja polityczna, a przede wszystkim procedura blokowania list sprawiły, że decydujący wpływ na kształt koalicji regionalnych mieli politycy ogólnokrajowi. Większość rozmówców wskazywała, że rozstrzygnięcia zapadały na poziomie centralnym: „To były centralne dyspozycje. To już było przygotowane w 2006 r., kiedy powstawała koalicja; już Tusk z Pawlakiem byli po słowie: blokowanie list w całej Polsce. Przecież to były decyzje po prostu podjęte w Warszawie, więc to była oczywista oczywistość” (respondent 8).

W związku z tym zaproponowane na początku tego artykułu pytania dotyczące roli ośrodka regionalnego i centrum, od tej kadencji przeformułowane zostały tak, aby dostosować się do rzeczywistości i określone jako stosunek do odtwarzania w województwach koalicji przystających. 


\section{PRZYSTAWALNOŚĆ KOALICJI CENTRALNEJ I REGIONALNYCH}

Budowanie koalicji przystających i unikanie koalicji krzyżujących w ramach systemu wielopoziomowego rozpoczyna się w 2006 r., choć w niektórych regionach koalicje takie powstają dopiero po wyborach parlamentarnych w 2007 r. Od tego momentu stały się one stałym wzorem do tworzenia koalicji regionalnych także po wyborach w 2010 i 2014 r. W związku z tym, w przypadku tych trzech kadencji (III, IV i V), uwaga skupi się nie tyle na indywidualnym opisie poszczególnych kadencji, ale raczej na odpowiedzi, dlaczego zjawisko to okazało się tak trwałe.

Odpowiedź na to pytanie warto jednak poprzedzić analizą jeszcze jednego zagadnienia: dlaczego w 2006 r. zaczęły powstawać koalicje przystające i dla kogo ważne było ich powstanie. Odwołując się do perspektywy wielopoziomowej, należy przypomnieć, że w I kadencji w ośmiu województwach istniały koalicje alternatywne SLD-PSL (choć definiowane w szerokim rozumieniu tego terminu, były to koalicje przystające - Linhart, 2016). Trudno jednak uznać je w oparciu o wywiady z marszałkami za efekt prowadzenia świadomej strategicznej polityki, odwołującej się do perspektywy wielopoziomowej. Co w takim razie zmieniło się w 2006 r.?

Rozważania dotyczące koalicji przystających warto rozpocząć od przedstawienia opinii marszałków rządzących województwami w 2006 r. na temat tego, kim był główny decydent. Należy zauważyć, że pomimo blokowania list, po wyborach wielu polityków w regionach było zwolennikami PO-PiS-u. Ukazuje to odpowiedź na pytanie, czy możliwa była koalicja z PiS: „Nie było na to zgody Warszawy, ponieważ starano się zbudować na poziomie sejmików koalicje na wzór koalicji rządowej, Platformy i PSL” (respondent 9).

Jednocześnie ten sam respondent, pozytywnie ocenia tę decyzję - sprzeczną $\mathrm{z}$ ich początkowymi oczekiwaniami; uznaje, że takie rozwiązanie jest korzystne z punktu widzenia regionu - zapewnia stabilność i przewidywalność w ramach prowadzonej na różnych „szczeblach” polityki: „Można by powiedzieć: dobrze widziana jest koalicja w układzie rządowym, jeśli nie ma jakichś zdecydowanych przeciwwskazań czy absolutnej niemożliwości współpracy, bo czasami personalia decydują, że ktoś z kimś nie może współpracować, ale to jest jakby kwestia drugorzędna. Pierwszorzędna to jest jednak odtworzenie tej koalicji rządowej, bo to generalnie wzmacnia cały układ, a jeśli koalicja rządowa jest odzwierciedlona na poziomie regionu, to jest dość stabilna sytuacja z punktu widzenia decydentów też... (...). Wzmacnia ich $\mathrm{w}$ relacjach $\mathrm{z}$ administracją rządową, tzn. daje takie poczucie, że można oczekiwać dobrej współpracy" (respondent 9). 
I również druga, podobna wypowiedź:

„A czy była rozważana koalicja z PiS?”(T.M.).

„Była” (respondent 10).

„I co zadecydowało, że taka koalicja...?” (T.M.).

„Decyzja władz krajowych. Wtedy podjęto decyzję, żeby zbudować sejmiki bez PiS-u. Platforma była w opozycji. I to było w 2006 r., wtedy, gdy PiS jeszcze rządził. I wtedy chciano te polityczne... Ktoś tam to mądrze myślał z punktu widzenia partii. PiS może nie do końca się orientował, jak ważne są sejmiki. Natomiast tam w Warszawie wiedzieli, jak ważne są sejmiki” (respondent 10).

Wypowiedź ta wskazuje na odrzucenie koalicji z PiS, choć w tym regionie również było ono postrzegane jako potencjalny partner. Powyższe cytaty zarazem jednoznacznie potwierdzają, że to Warszawa podjęła odpowiednie rozstrzygnięcia. Opinie te wyraźnie kontrastują z głosami marszałków poprzedniej kadencji sugerujących jakiś nie do końca określony wpływ centrum. Powtórzymy jeszcze raz fragment wypowiedzi marszałka II kadencji o wpływie polityków ogólnokrajowych: niewykluczone, że tutaj sugerowały dogadanie się...

Po drugie, co może być zakasujące, wypowiedzi te wskazują, że koalicje te nie były odbierane negatywnie jako przejaw centralizacji, ale postrzegane pozytywnie poprzez odwołanie się do perspektywy wielopoziomowej; to co jest korzystne dla partii, będzie także korzystne dla nich. W tym kontekście warto podkreślić znaczącą zmianę postaw marszałków, która nastąpiła po $2006 \mathrm{r}$. Była ona odzwierciedleniem zachodzących zmian politycznych: polaryzacji sceny politycznej, rozpoczętej w regionach wprowadzaniem procedury blokowania list. Warto podkreślić, że skuteczne tworzenie koalicji przystających od 2006 r., (i w trzech kolejnych kadencjach) było możliwe tylko dlatego, że polityka ta została zaaprobowana $w$ regionach. Ukazanie, jak radykalna była to zmiana postaw, dokumentuje krótki przegląd znacząco odmiennych opinii marszałków, kierujących województwami do $2007 \mathrm{r}$.

\section{STOSUNEK DO TWORZENIA KOALICJI PRZYSTAJĄCYCH W OPINII MARSZAŁKÓW RZĄDZĄCYCH WOJEWÓDZTWAMI DO PRZEŁOMU 2006/2007 R.}

Tworzenie koalicji przystających było postrzegane przez nich jako zjawisko przejściowe i raczej występujące w ograniczonej liczbie regionów, które może się pojawić, ale do którego raczej nie należałoby dążyć. Wskazywano na ograni- 
czone zalety tego typu rozwiązań, congruence budziła przede wszystkim poważne wątpliwości. Podkreślano odrębność samorządów i to, że punktem odniesienia dla kształtowania polityki regionalnej powinni być wyborcy i społeczność regionalna.

Innymi słowy, perspektywa, którą akcentowali marszałkowie do przełomu lat 2006/2007, to niezależność samorządów i autonomia w polityce regionalnej. Lepsza koordynacja polityki i współpraca $\mathrm{z}$ rządem tworzonym przez te same partie polityczne była dostrzegana, ale jako wartość nadrzędną wskazywano na możliwość dokonania wyboru w regionie. Jeszcze dobitniej te wartości ukazuje poniższy cytat. W tym przypadku jakakolwiek forma koordynacji wielopoziomowej w ramach partii była odrzucona, gdyż wywoływała bardzo silne skojarzenia z okresem PRL-u, narzucanie swej woli i podporządkowanie „niższych szczebli” administracji decyzjom KC PZPR.

„Zasugerowano mi w trakcie wywiadów z innymi marszałkami, że w wielu przypadkach struktury centralne partii podejmowały decyzję, z kim ma być koalicja?” (T.M.).

„T. [nazwisko jednego z przywódców partii - wtrącenie TM] do mnie nigdy nie zadzwonił. (...) Ale on do mnie nie zadzwonił z jednego powodu, bo wiedział, że jeżeli zadzwoni i powie, że ja mam coś zrobić: to ja mu powiem, że on ma swoje zabawki w Warszawie i w partii, i niech się nimi bawi, a ja mam swoją robotę tu i niech się ode mnie odczepi. Wszystko, koniec rozmowy. Ja po prostu pamiętam czasy, kiedy towarzysz sekretarz z komitetu dzwonił: wicie, rozumiecie, myśmy tu na egzekutywie postanowili..." (respondent 11).

Kolejna wypowiedź poniżej; również ten marszałek był głęboko przekonany, że tworzenie koalicji przystających było w interesie centrum, ale nie samorządów. Nie uważał takich koalicji za wyraz koordynacji politycznej przynoszącej korzyści obu stronom, ale podporządkowanie regionów centrum: „Jeżeli chodzi o samorząd, gdyby nie było tego zapotrzebowania na tworzenie tutaj wyraźnych podziałów. To by się układało w regionach w poprzek [koalicje - wtrącenie TM]. Na pewno nie byłoby takiej polityki (...). Ci, którzy są w Warszawie, chcą mieć jakieś przełożenie na teren i również tą swoją odrębność pokazywać, to te koalicje są wymuszane politycznie" (respondent 7). 


\section{TRWAŁOŚĆ KOALICJI PRZYSTAJĄCYCH I ZMIANA POSTAW PO PRZEŁOMIE 2006/2007 R}

W związku z trwałym trendem do tworzenia koalicji przystających ich analiza poszerzona zostanie o ocenę argumentów wskazujących na korzyści związane $\mathrm{z}$ ich funkcjonowaniem. W rozmowach $\mathrm{z}$ marszałkami dwa rodzaje argumentów uznawane były za priorytetowe. Po pierwsze: wymiar polityczny - skuteczne funkcjonowanie partii politycznej, jak i realizacja programów rządu i samorządu postrzegane były jako te, które wymagają współdziałania na poziomie centralnym i regionalnym. Po drugie, dla wielu rozmówców ścisła współpraca polityczna - konieczność prowadzenia polityki wielopoziomowej - związana była $z$ dostępem do funduszy europejskich. Dla wielu był to najważniejszy argument i dla niektórych $\mathrm{z}$ nich jedyny.

W opinii wielu rozmówców, jak już wspominano, najważniejszym czynnikiem wymuszającym ścisłą współpracę pomiędzy centrum i regionami była chęć jak najlepszego wykorzystania funduszy europejskich: „Myślę, że bardzo dobrze, że się tak złożyło. (...) Natomiast czy jest taki nacisk aż wielki, to myślę, że niekoniecznie, ja tu nie odczuwam z poziomu województwa. takiego nacisku. A z drugiej strony, jeśli chodzi o sprawność wykorzystania funduszy europejskich, to jeśli jest takie przełożenie, to sprzyja. Skuteczność działań na poziomie regionów jest dużo wyższa, jeśli ta koalicja jest odzwierciedleniem koalicji krajowej. Oczywiście, komunikacja, łatwość docierania do resortów. (...) Poza tym to jest przełom (...) w historii tej najnowszej nie pamiętam czegoś takiego, żeby się koalicja powtórzyła i tak zgodnie funkcjonowała. To jest wielkie osiągnięcie, że (...) tak wykorzystaliśmy pięknie środki europejskie, że Polskę możemy postawić dzisiaj za wzór. Jesteśmy najskuteczniejsi, mamy najmniej zwrotów pieniędzy w tych środkach europejskich. (...) Myślę, że właśnie dzięki takim koalicjom jest właśnie ta skuteczność (...)” (respondent 12).

Po 2006 r. partie polityczne zaczynają być coraz częściej postrzegane przez rządzących marszałków jako struktury wieloszczeblowe: „W partii politycznej (...) konieczna jest hierarchia: bo jest zarząd krajowy, jest porządek regionalny, także wykonujemy wskazania, czy też uchwały zarządu również krajowego. $\mathrm{Na}$ poziomie krajowym jest koalicja PO-PSL. Ja osobiście uważam, że naturalne jest, że również na poziomie regionalnym są te same koalicje. Wtedy jest łatwiej również o porozumienie z ministrami. Są to też powiązania. (....) Łatwiej jest współpracować, współdziałać, bo nasze programy regionalne muszą wpisywać się w rządowe programy, żeby osiągnąć lepsze powodzenie, bo nie tylko korzy- 
stamy z własnych środków, ale bardzo dużo z programów krajowych, które współfinansują inwestycje, np. [następuje opis inwestycji drogowych - wtrącenie TM]. Mamy świetnie skomunikowany region, dzięki polityce rządu tej koalicji PO-PSL" (respondent 12).

I również drugi cytat poniżej wskazuje na konieczność prowadzenia przez partię spójnej polityki na obu poziomach: centralnym i regionalnym. Dostrzec zarazem warto pewne różnice w rozłożeniu akcentów, wydaje się, że w wypowiedzi drugiej relacje są raczej partnerskie i podkreślana jest też zbieżność celów; koalicja z PSL odbierana jest jako bardzo korzystna z punktu widzenia regionalnych polityków $\mathrm{PO}$. Na koniec cytat ten ukazuje, że również w warunkach polskich niektórzy marszałkowie wysoko cenili dotychczasowe koalicje ${ }^{7}$ (incumbment coaltions; Warwick, 1966 [za:] Ştefuriuc, 2013) i czynnik ten silnie też wpływał na preferencje aktorów regionalnych: „Oczywiście z punktu widzenia tych moich dotychczasowych doświadczeń, ten wpływ centralny był, i to nawet, powiedziałbym, dosyć duży, bo w 2006 r., kiedy Platforma i PSL doszły do władzy (....), wówczas miała miejsce instytucja blokowania list. I my wówczas mieliśmy z PSL-em zablokowane listy, co za tym idzie, już przedtem umówiliśmy się na to, że będziemy razem ze sobą funkcjonowali na poziomie regionalnym, a w 2007 to się później przeniosło na szczebel centralny. Można powiedzieć, że (...) te uzgodnienia były najpierw na poziomie politycznym, następnie po wyborach zostało to dopięte i nie było specjalnie możliwości, żeby regiony (a na przykład, wtedy pamiętamy, że jeszcze były (...) jednak te sentymenty do PiS-u dosyć duże, żeby Platforma z PiS-em się gdzieś dogadywała). Raczej wtedy była jasno zaznaczona linia polityczna; NIE - to PSL ma być naszym strategicznym partnerem. Natomiast już po następnych wyborach to było na tyle naturalne, bo my jako środowiska na tyle się gdzieś zżyliśmy, że to nie musiało być centralnie uzgadniane. Oczywiście pytanie, jak będzie wyglądało to po tych kolejnych wyborach, bo ja uważam, że ja lubię pewną czytelność sceny politycznej i co za tym idzie, uważam, że tak powinno to funkcjonować. Tak funkcjonuje to w dojrzałych demokracjach, że jest takie wskazanie lub przynajmniej zarysowanie pewnych preferencji na poziomie centralnym. Tego, komu z kim blisko do realizacji poszczególnych programów, dla mnie to jest bardzo ważne. (...) Ja

7 Badania prowadzone w ramach MLG, wskazują, że większe prawdopodobieństwo powstania ma koalicja, która istnieje w momencie prowadzenia przetargów koalicyjnych, np. po kolejnych wyborach (Bäck i in., 2013, Bäck i in., 2009; Ştefuriuc, 2013; Debus, 2008; Däubler, Debus, 2009). 
lubię, gdy te układy są czytelne i gdy są jakoś wyznaczane w oparciu o to, co się dzieje na centralnej scenie politycznej" (respondent 14).

Wielu marszałków po $2006 \mathrm{r}$. definiowało samorząd regionalny jako poziom, na którym prowadzona była działalność polityczna; obszar zdominowany przez aktywność partii ogólnokrajowych. Uznawali to zarazem za zjawisko pozytywne właśnie w kontekście spójności realizowanych programów. Odrzucano istniejący wcześniej mit apolityczności, któremu towarzyszyło postrzeganie tego poziomu samorządu jako aktywności stowarzyszeń, komitetów czy innych struktur samorządowych, jednocześnie odrębnych od tych funkcjonujących w centrum. Poniżej cytat ilustrujący poglądy marszałków po 2006 r.: „To jest poziom polityczny, powiedzmy sobie szczerze. Poziom regionalny przy dużych regionach, a takie są polskie regiony, może nie wszystkie, ale to jednak są duże województwa. (...) To nie może być abstrakcja taka, że to sami samorządowcy, jeszcze wybrani w jednomandatowych okręgach, tutaj będą za wszystko odpowiadali. Jak będą mieli po jednej stronie partyjny rząd, a po drugiej stronie niżej, nie w sensie zależności, tylko w sensie funkcjonowania, jakieś zupełnie zatomizowane władze powiatów i gmin. (...) A to takie opowiadanie tam różnych historii, że to sami samorządowcy bez tych związków politycznych, to nie ma racji bytu. Oczywiście, na poziomie powiatów, gmin, choć już nie dużych miast, (...) polityka nieuchronnie jest tutaj, podobnie jak we wszystkich krajach UE, nie tylko w Polsce" (respondent 15).

I jeszcze jedna wypowiedź wskazująca, jak bardzo we współczesnych demokratycznych państwach ważna jest ścisła współpraca pomiędzy poziomem centralnym i regionalnym: „Nie można funkcjonować bez wpływu polityki centralnej na władze w regionach. To są zbyt duże organizmy, żeby dało się zupełnie uciec od polityki - to jest naturalne. Ja nie widzę nic złego w tym, że w jakiś sposób również liderzy partii w kraju, czy zarządy partii w kraju, rozmawiają o tym i potem, w taki czy inny sposób przekazują wskazówki czy zalecenia. (...) To jest wygodniejsze, nie zostawia jakichś tam znaków zapytania. Nie jest to też tak, że coś można nadzwyczajnie uzyskać, bo jednak prawo i procedury nas obowiązują, ale wiadomo, że gdzieś z pierwszej ręki coś można wiedzieć, to jest też bardzo ważne, szczególnie w regionie. Łatwiej jest o tę informację, jeżeli mamy do kogo zadzwonić w centrali" (respondent 16).

Jak pokazują powyższe cytaty, postrzeganie korzyści związanych ze współpracą pomiędzy regionami i rządem w sytuacji istnienia koalicji przystających zdominowały argumenty dotyczące spójności realizowanych programów politycznych (znaczenie tej kwestii było zintensyfikowane ze względu na dostęp do funduszy 
europejskich), jednak pełne zrozumienie wymiaru politycznego wymaga odwołania się do podziałów politycznych po 2006 r. i polityki międzypartyjnej. Warto rozważania te rozpocząć od cytatu opisującego realia polityki regionalnej w Polsce od około 2006 r., w konsekwencji istniejących wówczas podziałów politycznych: „Trudne pytanie. W zasadzie osobiście mam takie przekonanie, że powinniśmy posiadać jednak swobodę w kształtowaniu koalicji na poziomie regionalnym, co wcale nie znaczy, że zawarlibyśmy inną koalicję niż tę, którą zawarliśmy. Wiele nas różni, z pewnością w podejściu na przykład z Prawem i Sprawiedliwością. Ale ja myślę, że gdyby radni Prawa i Sprawiedliwości mieli swobodę w podejmowaniu decyzji, to ja myślę, że w wielu aspektach byśmy się dogadali. Natomiast, jeśli z ich strony, niemalże w sposób ideologiczny, jest zakaz podejmowania takiej a nie innej uchwały, żeby nie być gołosłownym, to podam przykład: komercjalizacja szpitali. Każdy z tych radnych doskonale rozumie, że w tych przypadkach, w których my podejmowaliśmy decyzje o komercjalizacji, to z pewnością każdy z nich indywidualnie, gdyby miał taką swobodę, podjąłby taką samą uchwałę. Czyli nie byłoby różnic pomiędzy decyzjami, które podejmują radni Platformy i radni PiS-u, ale tej swobody nie ma ani PiS, ani Platforma. Zakres tej swobody jest niestety wyznaczany odgórnie, to jest taka konstrukcja partii politycznych. Partie polityczne są scentralizowane, nie mają charakteru wprost regionalnego i w istocie to władze krajowe w dużej mierze decydują o kształcie polityki partyjnej, a niestety na szczeblu regionalnym one występują właśnie na poziomie partyjnym. To nie jest dobre, bo ja uważam, że mogą istnieć zasadnicze różnice w polityce regionalnej i krajowej. Mogą istnieć te wynikające ze specyfiki regionalnej. (...) I wtedy koalicje mogłyby być zawiązywane w zupełnie inny sposób. Fakt, że scena polityczna w Polsce się bardzo spolaryzowała, uniemożliwia wykształcenie się takich współzależności koalicyjnych, ale przecież występują też specyfiki regionalne. W jednym województwie na przykład funkcjonuje mniejszość narodowa, w jeszcze innym pojawiały się inicjatywy typowo samorządowe i też wprowadziły radnych" (respondent 17 ).

Wnioskiem wynikającym z przedstawionego w tym cytacie opisu sytuacji jest, że koalicje przystające są efektem centralizacji partii politycznych, które przenoszą i utrwalają na „szczeblu” regionalnym ogólnokrajowe podziały polityczne (clevages) właśnie poprzez taką ich konstrukcję. W związku z tym słabnie znaczenie tego, kto podejmuje decyzję o kształcie koalicji regionalnych. Nawet gdyby aktorzy regionalni mieli w tej kwestii autonomię, to zapewne byliby też zwolennikami koalicji przystających (nie przecinających głównego ogólnokrajowego podziału na rząd i opozycję). Zarazem rozmówca dostrzega, że zmiana 
tej sytuacji możliwa byłaby wraz z okrzepnięciem partii regionalnych (początki tego typu ewolucji już dostrzega).

Opinia o tendencjach do centralizacji partii politycznych jest dość powszechna wśród marszałków, dokumentuje to także kolejna wypowiedź: „Nasze regiony są też takie trochę scentralizowane. (...) W dużej mierze to, co się dzieje w regionach, kreuje się w Warszawie. I nawet poprzez programy regionalne i poprzez programy centralne. Środki unijne w dużej mierze, czy w większości są w programach centralnych. Zatrzymane są tam pieniądze i nie ma tej swobody, że tutaj dysponowany jest ten pieniądz" (respondent 18).

\section{ZAKOŃCZENIE}

W badanym okresie rola aktorów regionalnych i centralnych w procesie zawierania koalicji regionalnych ulegała zasadniczym zmianom. Wyodrębnić można dwa okresy. Pierwsza faza to dominacja regionu; I i II kadencja, choć w każdej z nich inne były czynniki rozstrzygające o tym, że to politycy regionalni podejmowali kluczowe decyzje dotyczące polityki koalicyjnej. W I kadencji silna pozycja aktorów regionalnych wynikała przede wszystkim $\mathrm{z}$ faktu, że centrum nie do końca dostrzegało znaczenie samorządu województwa. Po drugie możliwość koordynacji wielopoziomowej utrudniało to, że struktury regionalne partii dopiero się kształtowały. W II kadencji natomiast rozdrobnienie polityczne ograniczało możliwość wywierania wpływu przez polityków centralnych. Zasadnicza zmiana zachodzi na przełomie lat 2006/2007, od tego czasu w województwach tworzone są koalicje przystające, a w sytuacjach, w których nie było to możliwe, unikano tworzenia koalicji krzyżujących, w skład których wchodziłaby główna partia opozycyjna (PiS). Na koniec warto zauważyć, że koalicje przystające postrzegane są także jako korzystne dla aktorów regionalnych PO i PSL, na co wskazuje utrzymanie się ich także po wyborach parlamentarnych w 2015 r. Wówczas porozumienia te stały się koalicjami alternatywnymi, a w oparciu o literaturę przedmiotu można było oczekiwać, że zmiana w centrum pociągnie za sobą także zmiany koalicji regionalnych. Odbiega to także od dotychczasowych trendów dotyczących zmian koalicji wojewódzkich po wyborach parlamentarnych (po wyborach w 2001 oraz w 2005 r. zwiększała się liczba koalicji; w skład których wchodziła główna partia rządowa; oznaczało to równocześnie zmniejszanie się liczby koalicji alternatywnych, a po wyborach w 2007 r. zmniejszyła się liczba koalicji krzyżujących). 
BiBLIOGRAFIA:

Bäck, H., Debus, M., Müller, J., Bäck, H. (2013). Regional Government Formation in Varying Multilevel Contexts: A Comparison of Eight European Countries. Regional Studies, 47(3), s. 368-387.

Bäck, H., Debus, M., Bäck, H. (2009). Regional Government Formation in Varying Multi-Level Contexts. A comparison of Germany, Netherlands, Spain and Sweden. Santiago de Chile: IPSA World Congress of Political Science, 12-16.07.2009. Pobrane z: https://ecpr.eu/Filestore/PaperProposal/a8468df7-3878-469a-988a-362fce9a09bb. pdf.

Däubler, T., Debus, M. (2009). Government Formation and Policy Formulation in the German States. Regional \& Federal Studies, 19(1), s. 73-95.

Debus, M. (2008). Party Competition and Government Formation in Multi-Level Settings: Evidence from Germany. Government and Opposition, 43(4), s. 505-538.

Deschouwer, K. (2001). Multilevel Systems and Political Careers: The Pleasures of Getting Lost. Grenoble: ECPR Joint Sessions of Workshops, 6-11.04.2001.

Deschouwer, K. (2009). Coalition Formation and Congruence in a Multi-layered Setting: Belgium 1995-2008. Regional \& Federal Studies, 19(1), s. 13-35.

Downs, W.M. (1998). Coalition Government, Subnational Style. Multiparty Politics in Europe's Regional Parliaments. Columbus: Ohio State University Press.

Grabowska, M. (2004). Podział postkomunistyczny. Społeczne podstawy polityki w Polsce po 1989 roku. Warszawa: Wydawnictwo Naukowe Scholar.

Grają na dwa fronty. (2004). Gazeta Wyborcza Łódź.

Kowalska, M. (2004). Polityczne Prawo i Sprawiedliwość. Gazeta Wyborcza Wrocław, 6.12.2004.

Kwaśniewski, M. (2002). Koalicja wpływów. Gazeta krakowska, 21.11.2002.

Linhart, E. (2016). Coalition Building on the Federal and on the Länder Level in Germany. Poznań: IPSA World Congress of Political Science, 23-28.07.2016. Pobrane z: https://www.researchgate.net/publication/305709804_Coalition_building_on_the_federal_and_on_the_Lander_level_in_Germany.

Łódź: Samoobrona rozwodzi się z SLD. (2003). RMF FM, 07.02.2003. Pobrane z: www. rmf.fm.

Majcherkiewicz, T. (2016). Wzory tworzenia wojewódzkich koalicji samorządowych a skład polityczny zarządów województw w latach 1998-2014. Studia polityczne, 42(2), s. 113-144.

Majcherkiewicz, T. (2017, w przygotowaniu do druku) Koalicje regionalne w perspektywie rządzenia wielopoziomowego. Studia polityczne.

Nikolski, L. (2011). Partie polityczne w wyborach do sejmików województw 1998-2006. Toruń: Wydawnictwo Adam Marszałek.

Pappi, F.U., Becker, A., Herzog, A. (2005). Regierungsbildung in Mehrebenensystemen: Zur Erklärung der Koalitionsbildung in den deutschen Bundesländern. Politische Vierteljahresschrift, 46(3), s. 432-458. 
Raciborski, J. (2006) Konstruowanie rządów i elit rządowych. W: J. Raciborski (red.), Elity rządowe III RP 1997-2004. Portret socjologiczny, (s. 27-50). Warszawa: Wydawnictwo Trio.

Ştefuriuc, I. (2013). Government Formation in Multi-Level Settings: Party Strategy and Institutional Constraints. Basingstoke: Palgrave Macmillan.

Warwcik, P. (1996). Coalition Government Membership in West European Parliamentary Democracies. British Journal of Political Science, 26(4), s. 471-499. 
[76]

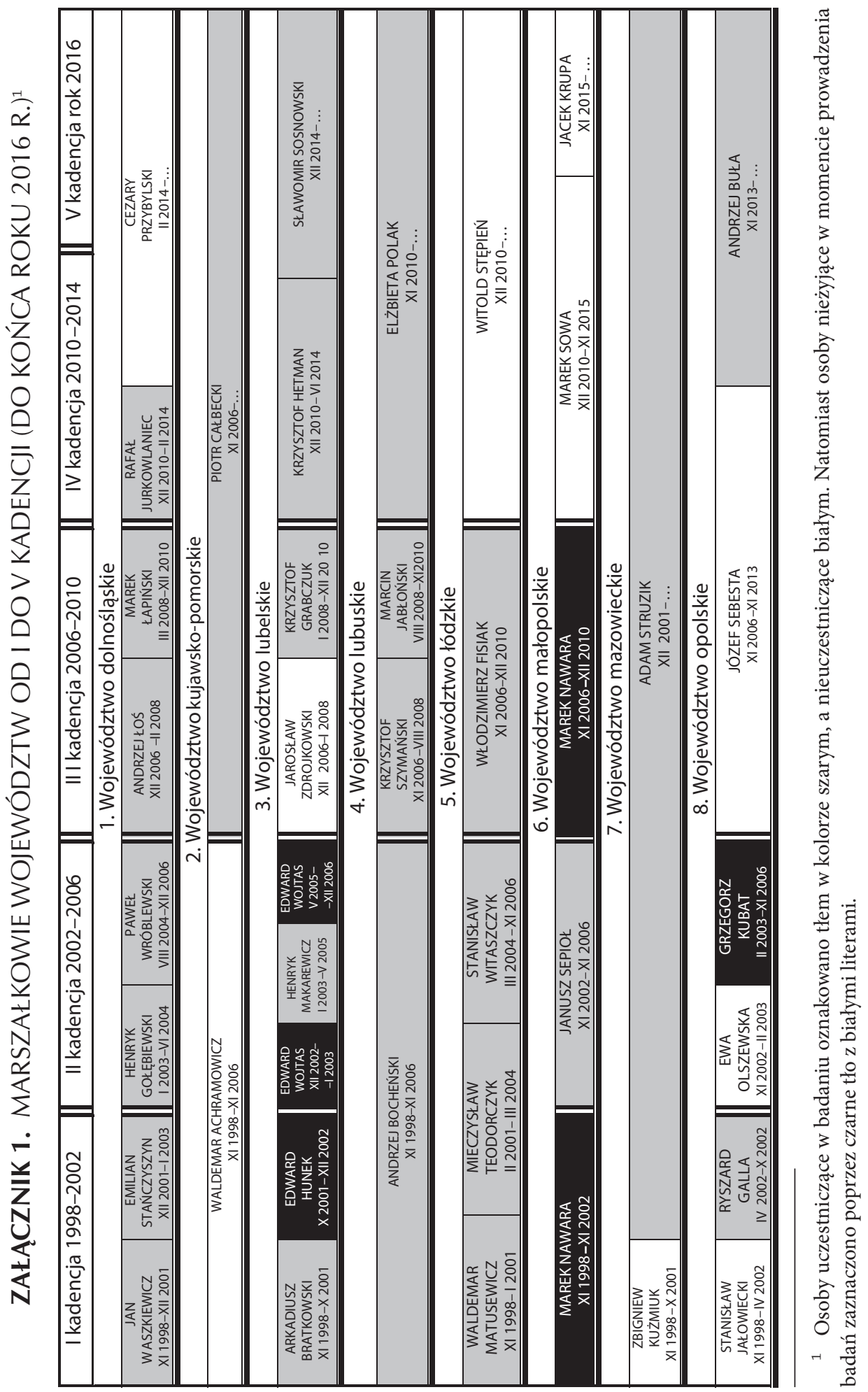




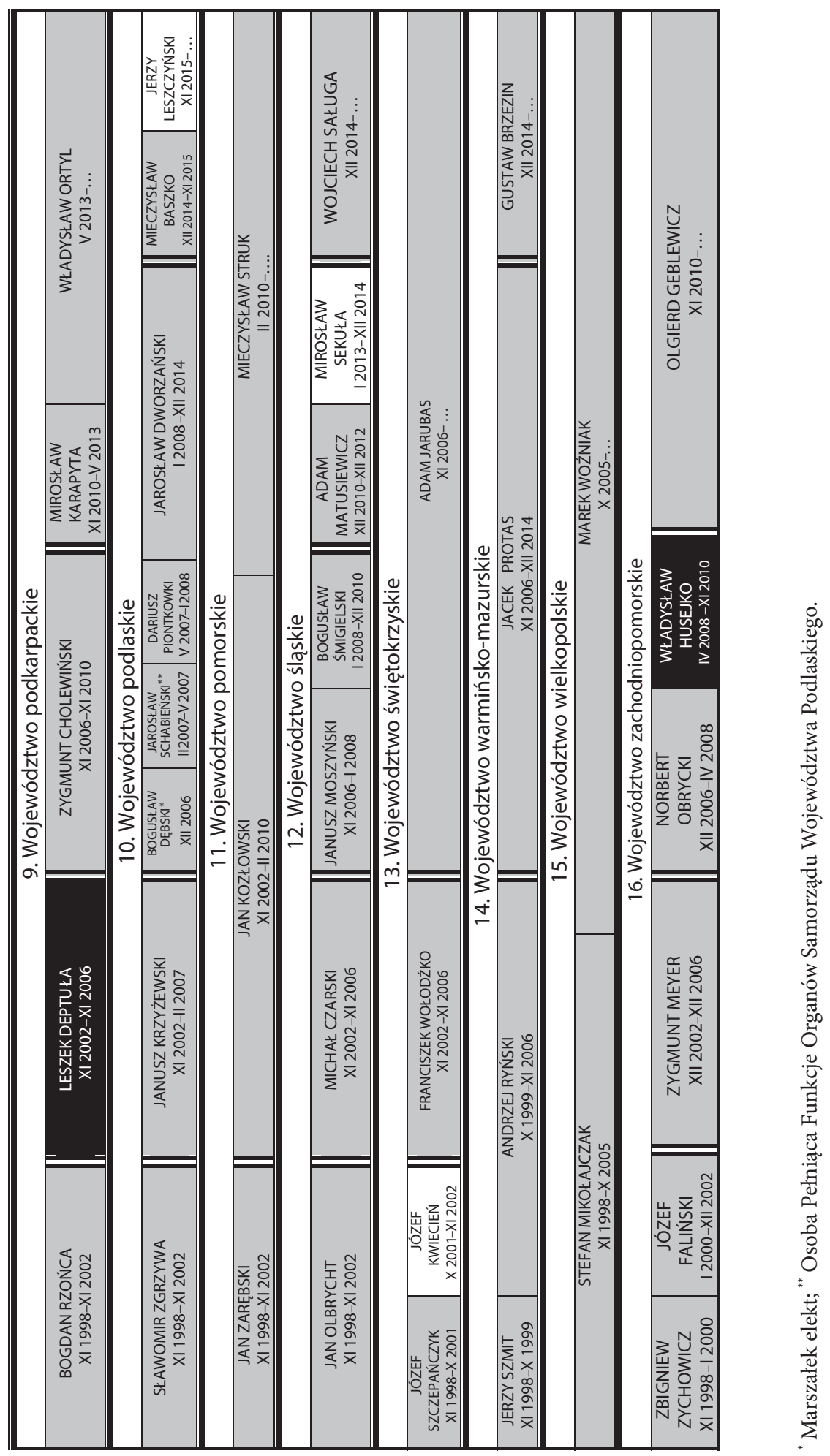

[77] 